\title{
Symbolic Capital of Hindu in Local Islamic Sasak Ethnic Ritual in Bayan District
}

\author{
I Wayan Wirata \\ Mataram State Hindu Collage of Gde Pudja \\ Mataram, Indonesia \\ iwayanwiratastah@yahoo.co.id
}

\begin{abstract}
Tradition and religion local Islamic Sasak ethnic ritual in Bayan district often use ritual symbols as sacrificial. The existence of symbols used is one of Hindu capital's identity in Panca Yadnya ritual, such as big ceremony (begawe beleq). Furthermore, in the social structure symbol of local Islamic figure in Bayan district has similarities with Hindu. The three central figures pervade: Pemangku, Pembekel, and Penghulu. Pemangku is in charge for customs and agriculture in his village, Pembekel is dealing with village government and marriage, and Penghulu is in charge to overcome religion and death. Religious regulation is always performed using sacred symbols in ritual activity at Pedewak, Old Mosque (Masjid Kuno), and tomb. As for traditional rituals and religious symbols of local Islamic Sasak Ethnic, in principle can be divided into three types associated with traditional religion (gamma), customs outside religion (lwir gamma) and customs related to life and death.
\end{abstract}

Keywords: Symbolic Capital of Hindu and Local Islamic Sasak Ethnic Ritual

\section{INTRODUCTION}

In the tradition of local Islamic community of Sasak Bayan tribe performs everyday activities using many symbols Hindu's ritual. For instance related ritual to traditional religious (gamma), customs outside religion (lwir gamma), and related customs to life and death. During the ceremony contained a specific meaning or symbol that gives meaning and value to the society. Indonesia old symbols or art store hidden values that not only coat the surface, but its meaning has been explored as a means towards a divine transfiguration, symbolic, camouflaged, and transcendent especially in the era of Islam[1].

In general, religious ritual of local Islamic community of Sasak Bayan tribe more accentuate local culture in its religious traditions despite their religious practices are sometimes at odds with the pure Islam. This is confirmed by Aziz[2]. explains that the existence of socio-cultural values that are implemented in a number of traditions, both concerning the normative aspects as well as the practice of ritual ceremony, reflected on indigenous peoples.

\section{DISCUSSION}

In the implementation of the tradition ceremonies of local Islamic community of Sasak Bayan is led by traditional leaders that have been agreed by the society. The purpose of the tradition ceremonies of Local Islamic Sasak Bayan is begging spiritual and physical welfare of society towards harmonious, secure, and peaceful.

\subsection{Gamma Ceremony}

The Gamma tradition ceremony is basically conducted in places of worship such as Masjid (mosque) and tomb. This ceremony aims to balance or preserve the universe and its contents to the welfare of the physically and mentally. Ceremony of Gama tradition includes the following ceremony.

\section{A. Alif Year Ceremony}

Alif ceremony takes place every one windu (once in eight years) and is always perpetrated based on Sasak's calendar calculations. The purpose of Alif ceremony is seeking guidance and grace to the Almighty God for all creation (humans, plants, and animals), and are granted as well as the welfare and protection so that they can carry out their life processes well. This is consistent with the concept of Rsi Gana in Hindu to regularize the micro and macrocosm along with the content to be harmonious and balanced. This is in line with the opinion of Rasti[3] explains that the local community of Islam (Wetu Telu) have a religious social structure refers to the traditions and beliefs that have been received from their ancestors.

\section{B. Tilawat Ceremony}

Tilawat ceremony is held after Begawe Alif has been done. The purpose of this ceremony is carried out as follows: a) pray for safety, prosperity, and harmony of the whole family, relatives, and society in the near future; b) to avoid evil, hatred and danger; c) ask forgiveness for all the sins that have been done so that the guidance given in the right direction; and d) pray to get enough income in the near future. Implementation is in accordance with Manusa Yadnya ceremony in the Hindu ritual that is praying to keep in harmonious, safe, serene, and peaceful.

In the implementation of this Tilawat ceremony, followed by the reading of the holy verses of al-Quran at home or at mosque. In general, the reading of the Qur'an is done for 24 hours with ngaji (reading Qur'an), so it is often termed ceremony Tilawat with the term Ngaji Tilawat [4]

\section{Lebaran Topat Ceremony}

Eid ceremony in principle is a ceremonial gathering to relatives associated with mutual forgiveness among others. By executing this event is expected not occur animosity or anger toward everything that has happened before, but it can eliminate the taste and feeling good so as to increase the sense 
of tolerance and mutual respect between one another. Eid ceremony is divided into 3 (three), namely 1) Idul Fitri/Eid high, which was held on the 3rd of Shawwal; 2) Eid alAdha/short widths; and 3) Topat Ceremony (Eid ceremony by offering Topat (rice cake) to enliven the occasion of Eid). Lebaran Topat is usually held on the eighth day after the day of Eid, which is carried out by Islamic Eid in conjunction with the ceremony Kemalik (temple ceremony) Panca Yadnya Hindus in Lingsar Temple.

\subsection{Indigenous of Lwir Gama}

Traditional Lwir Gama ceremony can be held associated with the season over one year. This ceremony aims to appeal to Allah (God Almighty) so that all plants are grown or cultivated to get a plentiful harvest (gemah ripah luh jinawi) and farmers, breeders and fishermen to protected from the disasters, the bad influence when cultivating the soil, fields, herding and down to the sea.

In general, the local Islamic community of Sasak Bayan carries out farming activities begins with Mbangar ceremony called Toak Lokak Nggawi Gumi sky. By tradition handed down every execution ceremony Mbangar created a courtyard made of stone to lay an offering as treat the gods that exist in the fields to be given treats in order to protect and maintain the fields from outside influences disrupt and damage of the plagues override. Thus the aim is also to repel bakik berak (a kind of genie or devil) that are considered disturbing the growth and development of plants that live in their rice fields. The same thing in accordance with the explanation by Marjanto[5] explains that fundamental changes show trend development paradigm that is more humane and more "cultural", because it provides a space for improvement local cultural. Local wisdom is a special place, because it is considered as a source of inspiration for the settlement of various issues, so that the local wisdom that has been largely abandoned by the society need to be introduced and revived.

The ceremonies which are perpetrated in relation to cultivate and maintain, eliminate pests and diseases of rice, according to Local Islamic community of Sasak Bayan is as follows. The noble values of national culture are desirable ideals of the Indonesian nation. These noble values is a reference to the behavior in real life, and if it all takes place consistently enforced and consequently, it will behold the identity or the identity of the nation Indonesia[6].

\section{A. The Ceremony of Salvation Seeds (Nyelamet Binek)}

The ceremony was conducted in order to provide safety upon the seeds that have been planted that eventually flourished, productive and avoided from death. The ceremony is held when the seed was seven days. Offerings were made in a series of ceremonies that concoction is called bubus offerings consist of meringue leaves, rice, and bamboo child (rembung). This ceremony aims to avoid the planted seedlings free of pests and diseases, so that farmers can improve the productivity of their crops.

\section{B. Nyelamet Lowong Ceremony}

The ceremony is carried out when the plant at the age of 30 days after the seeds are planted. This ceremony aims to convey the gratitude and thanks to Sepengkula (God Almighty) that rice planted can grow up, so that farmers feel the desire to implement the farming operation. Serve offerings of gratitude in the form of rice with side dishes to taste, eggs, meat, beef, rampe, incense and holy fire. Once completed rowah (eating together) with family or relatives on rizki given by Sepengkula (Allah) to his people. For that ceremony of nyelamat rowah often referred to as rowah ceremony. The same thing was confirmed by Budiwanti[7] explains that the anthropological approach to Local Islamic community of Sasak in Bayan district in daily tend to ignore the true Islamic practice because they revere the spirits, gods, and other traditions and Hindus in general.

\section{Nyelamet Sampi Ceremony}

Nyelamet Sampi ceremony is conducted by the local Islamic community of Sasak Bayan when cows are used for plowing fields. This ceremony aims to keep cows healthy in order the energy can be used for working the fields, which can lead the production in order to meet the needs of the family. In addition, it can provide new energy sources such as meat, where the cattle are slaughtering as a source of energy for human growth.

\section{Nunas Sesari Ceremony}

This ceremony aims to pray endowing grains so many pithy with saris rice, in order the rice production can be plentiful. This ceremony is carried out by means of an offering in the form of red pulp (bubur beak) and white porridge (bubur putik) made from rice flour that comes with other facilities like betel leaf, betel nuts, flowers, potpourri and holy water. The offering is offered to Dewi Sri as a manifestation of the Goddess of fertility, so that rice plants can grow normally.

\section{E. Bedede Lowong Ceremony}

Basically, the belief of Islamic community of Sasak Bayan in every place inhabited by creatures that grow and develop there is occupying it (owner unseen). This ceremony aims to convey to the owner of supernatural (Epen Dowe) that the rice plants can grow well, produce optimally, in addition can grow and develop properly. The process of this ceremony is done by gathering together from entering the water (Namak Aik) by surrounding rice paddies through pradaksina (surrounding to the right) as the direction of clockwise and will stop at each corner of the field while cover leaves rice followed together.

\section{F. Bau Inan Beoran Ceremony}

The ceremony is held as a symbolic manifestation of activities preliminary harvest by picking a handful as Inan Pade (mother/parent of rice). The process of this ceremony is to deliver the offerings with an egg that has been put in a small pot called (tong becik). after this activity, then it is continued by picking activities that serve as the parent of rice as a manifestation of Dewi Sri Saelani (42 Years Old) said the decision to hang rice, reciting or reading the words:

Inaq bumbun sari, amaq bumbun sari, Kanekungeliningin epe, Ade'neberembun sarin epe, Inaq bumbun sari amaq bumbun sari, 
This means: Mother and father Bumbun Sari, I now surround them, to assemble the essences, mother father Bumbun Sari,

\section{G. Rice Salvation Ceremony (Selametan Pade)}

The ceremony was held as a form of gratitude for the results obtained after a long process until the rice fields can do harvest in fields. This event is usually held after the harvest and the rice after being inserted into the storage barn. In general, the ceremony was held at home by inviting family and friends as well as a prominent leader Kyai. This event was preceded by the reading of prayers and ate together as a sense of family and togetherness.

\subsection{Indigenous Life}

In human life always experience a life cycle from birth to death. From birth has always done a thanksgiving ceremony or salvation in order to obtain a physical and spiritual strength. Forms and types of ceremonies are performed depends on public trust and confidence to carry out in accordance with the abilities and traditions that have been passed down by his ancestors. In local Islamic society of Sasak in general perform traditional ceremonies associated with life are:

\section{A. Buang Awu Ceremony}

Buag Awu ceremony is held in order to introduce to the universe that human born have been able to already adapt to the environment and natural surroundings. This ceremony of the local Islamic community of Sasak Bayan tribe termed Memedak. Before the event Buang Awu first implemented pedaq empit's event is an event which deliberately extinguishing the fire ignited by the baby's father performed by shamans (healers). Furthermore, the flames in the fire flush with empit (water rice crust) mixed with a squeeze of pandan leaves and Bikan leaf and after the completion of the remove $A w u$ then it is event held meroah (thanks giving).

\section{B. Ngurisang Ceremony}

Ngurisang ceremony among the local Islamic community of Sasak Bayan has symbolic significance to remove or avoid the child's behavior is bad or negative and as well as foster a new spirit and innovation within the baby in preparing to pursue a better life journey towards the messenger trip.

\section{Marriage Ceremony}

Marriage was a meeting between a man and a woman based on mutual love for forming household intact (Sakinah). At the local Islamic community of Sasak tribe in West Nusa Tenggara generally in Bayan recognize four kinds of marriage systems, namely: a. Mekawin (consensual); b) Mulang (escape the woman he loved); c) Naikin (women come to the place of men); d) Ngelabu (men come and surrender to a woman).

\section{Death Ceremony}

People who live in the world are always through the process of life from birth until death. In death generally considered to be a final process in the life of this world. Thus no one in the world escaped death, both of which are old, young, and the young will all lead to the death. For humanity, the events of death will surely pick up his time including local Islamic community of Sasak Bayan Lombok West Nusa
Tenggara. Local Islamic society of Sasak Bayan had believed the existence of another life after life in the world, like life in nature of grave (barzakh).

With their funerals, then the local Islamic community of Sasak Bayan implemented before the funeral ceremony until the burial, namely: 1) a ceremony before the funeral; 2) funerals; and 3) the ceremony after the funeral. Pre-burial ceremony includes bathing the corpse, winding-sheet on, pray, as well as the excavation of grave sites. Burial ceremony includes the departure of the corpse to the grave, bury the body into the grave, and chanting, while the post-burial is reading prayers on certain days according to the development of society.

\section{a) Pre Funeral Ceremony}

At the local Islamic community of Sasak Bayan carries out activities on the first day of the death or by calling Kyai to recite Takbir (praying). Furthermore Kyai asks pemaran water as a symbol to certify the deceased. Syakur[8] explains that pemaran water serves to eliminate unpleasant odors are contained in the bodies, in addition as a preservative so the remains durable. Islam Sasak for last breathed is soon called Kyai for praying (Muslims of Local Sasak Bayan) and requested pemaran water, for other Sasak. Praying (takbir) and pemaran water each use to validate a person's death. After the body is washed and wrapped in a shroud and then the body is placed by the family in the pavilion (berugak) on the side of the bodies burned incense. The served portion of food is usually replaced three times a day (morning, noon, and night) and the food is served with rice called rice deceased or cruise.

The next step is the excavation pit was led by Kyai. Excavation is better known with the term tepong tana. Offerings that are taken when did tepong tana, is tukel yarn, lekesan (betel, areca nut, and lime) and broad money (kepeng bolong) which is odd number. Then after that a new body is taken to the cemetery for burial.

\section{b) Remains Funeral}

Before the body is put in a hole, Kyai first flush the hole three times with water contained in the jug which is prepared with the following order. The head watered three times, the middle three times, and the back three times. After watering is finished and then plant coin perforated at the center of hole of remains. Furthermore, the new Kyai lowered the bodies according to the Mecca by reading the prayer "'Bismilllahir Rahmanir rahim, tabe-tabe Ibu Hawa, Bapa Adam, Mirek Ibu Hawa, Bapa Adam, langan anak putuning Adam, which means the name of Allah the most gracious and the most merciful, excused Ibu Hawa Bapak Adam, menyingkirkan Ibu Hawa dan Bapak Adam, Jalan anak cucu Adam"[9]. Prayer and mantra are meant as a sign of submission of the bodies that are well accepted in the sight of Allah without any hindrance.

\section{c) After the Ceremony Pemakam Jenazah}

Besides life ceremonial, the local Islamic community of Sasak Bayan also carries out funeral rites reserved for those who have died for the ceremonies are conducted in accordance with Islamic customs of local Sasak Bayan in North Lombok 
Regency of West Nusa Tenggara. The concept of the death of Islam local tradition Sasak Bayan of bathing the corpse, winding-sheet on, praying, and come to bury.

After completion of burial accompanied by the reading of prayers and incantations, the second day is generally rare. The ceremony is then performed on the third day up until the day to a thousand. Stages of the ceremony as follows: Nelung for the third day, Mituk for the seventh day, and 3) Nyanga for the ninth day of the death. This is in accordance with the Hindu tradition in the implementation of the funeral ceremony (Pitra Yadnya).

\section{CONCLUSION}

Islamic religious ritual and local Sasak in Bayan district often use ritual symbols as an offering to God Almighty. The symbols used in general are symbol of the identity of Hindu rituals. As a symbol of the ceremony Dewa Yadnya, Manusa Yadnya, Rsi Yadnya, Pitra Yadnya and Bhuta Yadnya.

Local Islamic Sasak in Bayan district used the symbol of ritual as something that is considered to have supernatural powers. These symbols are used in sacred places like Pedewak, Old Mosque and Tomb, because it gives meaning and purpose in life as well as the motivation and enthusiasm for life for the people. The symbol of traditional rituals and Islam locally implemented in cultural activities such as traditional religion (Gamma), customs outside religion (Lwir Gamma) and customs related to life and death.

\section{REFERENCES}

[1] Sunaryo, Edi, Nur Sahid, dan Akhmad Nizam. 2016. "Ragam Hias Beberapa Masjid di Jawa: Kajian Sejarah Kebudayaan dan Semiotika. Mudra (Jurnal Seni Budaya) Vol. 31 No. 2. Institut Seni Indonesia Denpasar: Penerbitan isi-dps.ac.id.

[2] Azis, Abdul. 2014. "Proses Pelembagaan Nilai-Nilai Sosial Budaya Masyarakat Adat Karampuang di Sulawesi Selatan”. Jurnal Penelitian Sejarah dan Nilai Tradisional Vol. 21 No. 2. Laman: http://kebudayaan.kemdikbud.go.id/bpnbbali. Denpasar: PT. Percetakan Bali.

[3] Rasti, Ni Wayan. 2005. Wetu Telu di Kabupaten Lombok Barat Sebuah Kajian Teologi Hindu. "Tesis". Program Pascasarjana Institut Hindu Dharma Negeri Denpasar.

[4] Zaelani, Kamarudin. 2007. Satu Agama Banyak tuhan: Melacak Akar Sejarah Teologi Waktu Telu. Mataram: Pantheon Media Pressindo.

[5] Marjanto, Damardjati Kun. 2015. "Kearifan Lokal Upacara Ruwatan Rambut Gembel dan Hubungannya dengan Pelestarian Lingkungan di Kawasan Dieng". Jurnal Penelitian Sejarah dan Nilai Tradisional Vol. 22 No. 2. Laman: http://kebudayaan.kemdikbud.go.id/bpnbbali. Denpasar: PT. Percetakan Bali.

[6] Purna, I Made. 2015. "Memperkuat Jatidiri dan Karakter dalam Membangun ke-Indonesia-an Perspektif: Kebudayaan”. Jurnal Penelitian Sejarah dan Nilai Tradisional Vol. 22 No. 1. Laman: http://kebudayaan.kemdikbud.go.id/bpnbbali.

[7] Budiwanti, Erni. 2000. Islam Sasak. Yogyakarta: LkiS (Yayasan Adikarya IKAPI dan Ford Foundation).

[8] Syakur, A.A. 2006. Islam dan Kebudayaan "Akulturasi Nilai-Nilai Islam dalam Budaya Sasak". Yogyakarta: Adab Press.

[9] Syakur, A.A. 2006. Islam dan Kebudayaan "Akulturasi Nilai-Nilai Islam dalam Budaya Sasak”. Yogyakarta: Adab Press. 